\title{
DEVELOPMENT OF MODELS TO AID DECISION-MAKING IN THE MANAGEMENT OF Araucaria angustifolia (Bertol.) Kuntze
}

\author{
Isadora de Arruda Souza ${ }^{1 *}$, Andre Felipe Hess ${ }^{2}$, Emanuel Arnoni Costa ${ }^{3}$, Ana Claudia da Silveira ${ }^{4}$, Luis Paulo \\ Baldissera Schorr ${ }^{5}$, Kemely Alves Atanazio ${ }^{6}$ \\ ${ }^{1 *}$ Santa Catarina State University, Department of Forest Engineering, Lages, Santa Catarina, Brazil - isadoraarrudaengflorestal@gmail.com \\ ${ }^{2}$ Santa Catarina State University,Department of Forest Engineering, Lages, Santa Catarina, Brazil - hessandre@ yahoo.com.br \\ ${ }^{3}$ Federal University of Uberlândia, Forest Engineering, Monte Carmelo, MG, Brazil, emanuelarnonicost@ hotmail.com \\ ${ }^{4}$ Santa Catarina State University, Department of Forest Engineering, Francisco Beltão, Paraná, Brazil - anaclaudiasilveira@ hotmail.com \\ ${ }^{5}$ Departamento de Ciências Florestais, Federal University of Lavras, PhD in Forestry Engineering, Lavras, Minas Gerais, Brazil - \\ lpbs93@gmail.com \\ ${ }^{6}$ Federal University of Viçosa, PhD in Forest Science, Viçosa, Minas Gerais, Brazil - kemely_alves@ hotmail.com
}

Received for publication: 25/04/2019 - Accepted for publication: 08/09/2019

\begin{abstract}
Resumo
Desenvolvimento de modelos metemátiocos para auxilio à tomada de decisões no manejo de Araucaria angustifolia (Bertol.) Kuntze. A pesquisa operacional (PO) é uma ferramenta poderosa para a tomada de decisões na otimização do planejamento da produção florestal. Assim, o objetivo deste estudo é utilizar o PO para solucionar problemas de regulação florestal em uma floresta natural de Araucaria angustifolia (Bertol) Kuntze. A proposta de um melhor regime de manejo da floresta consistiu na elaboração de dois problemas de PO utilizando programação linear inteira (PLI). I - o primeiro com o objetivo de maximizar a receita de cada regime; e o II - o segundo com o objetivo de definir a melhor alternativa de gerenciamento para três valores do quociente q De Liocourt de 1,1; 1,3 e 1,5, áreas basais residuais de 10,0, 12,0 e 14,0 $\mathrm{m}^{2}$.ha- $\mathrm{e}^{-1}$ e ciclos de corte de 20, 25 e 30 anos, criando assim 27 cenários de manejo. Apesar da aplicação de ciclos de corte de 20, 25 e 30 anos, a alternativa de manejo que melhor aproveita os recursos e maximiza a receita para esta área de 84 ha, no município de Lages, $\mathrm{SC}$, é " $\mathrm{q}$ " =1,3 com residual basal área de $12 \mathrm{~m}^{2} \cdot \mathrm{ha}^{-1}$ para todos os ciclos de corte. A remoção dessas árvores da floresta contribuirá para a manutenção de uma futura estrutura diamétrica, regeneração natural, conservação de espécies e taxa de incremento de árvores, bem como a manutenção dos recursos do ecossistema florestal.

Palavras-chave: Quociente de De Liocourt, Programação linear, Regulação florestal.
\end{abstract}

\begin{abstract}
Operational research $(\mathrm{OR})$ is a powerful tool for decision-making in optimizing forestry production planning. Thus, the objective of this study is to use the OR to solve forest regulation problems in a natural forest of Araucaria angustifolia (Bertol) Kuntze. The proposal for better management regime for the forest consisted in the elaboration of two OR problems using integer linear programming (ILP). I - the first aiming to maximize income for each regime; and the II - second aiming to define the best management alternative for three values of the De Liocourt q quotient of $1.1 ; 1.3$ and 1.5 , residual basal areas of 10.0, 12.0 and $14.0 \mathrm{~m}^{2} . \mathrm{ha}^{-1}$ and cutting cycles of 20, 25 and 30 years, creating thus 27 management scenarios. Despite the application of cutting cycles of 20,25 and 30 years, the management alternative that best uses the resources and maximizes the income for this area of 84 ha, in the municipality of Lages, $\mathrm{SC}$, is "q" = 1.3 with residual basal area of $12 \mathrm{~m}^{2}$.ha- for all cutting cycles. The removal of these trees in the forest will contribute to the maintenance of a future diametric structure, natural regeneration, species conservation and tree increment rate, as well as the maintenance of resources of the forest ecosystem. Keywords: De Liocourt Quotient, Linear programming, Forestry regulation.
\end{abstract}

\section{INTRODUCTION}

Araucaria angustifolia (Bertol.) Kuntze, also known as Brazilian pine, is one of the most important forest species in Southern Brazil. Due to the disorderly exploration in the past, the use of forest areas for agriculture and increase in urban areas, the coverage area with Araucaria forest (Mixed Ombrophilous Forest - MOF) decreased. Thus, legal measures were taken to forbid the exploitation of species, such an attitude precludes the management of native areas of Araucaria forests. The purpose of the laws is to ensure preservation and conservation, but in reports such as the socio-environmental survey on the current inappropriate legislation, it is indicated as harmful to the future of the species (JUSTEN et al. 2012). Thus, the prohibition of forest management is detrimental to the conservation of forests without the proper application of sustainable management. Increment rates tend to stagnate (HESS et al. 2018b), there

FLORESTA, Curitiba, PR, v. 50, n. 4, p. 1854 - 1863, out/dez 2020.

Souza, I. A et.al.

ISSN eletrônico 1982-4688

1854

DOI: $10.5380 /$ rf.v50 i4. 66459 
is a reduction in the diversity of species, competition (COSTA; FINGER, 2017), low natural regeneration, low ingress rate, higher mortality and scarcity of resources of the forest ecosystem (ORELLANA; VANCLAY, 2018).

One of the challenges for forest management in small farms is to maintain a regular supply of timber, a prerequisite for its economic viability. The tool currently used for the best planning and decision making is the Operational Research (OR), which is defined as the area of knowledge that studies, develops and applies advanced analytical methods to assist in better decision making. OR is the tool chosen for the solution of forest problems as in the studies by Campos et al. (2013) and Orellana et al. (2014).

In the decision-making process to define the best management alternatives, they are commonly formulated as problems of linear programming (LP) and integer linear programming (ILP) (GOMIDE et al., 2009). This is understood as a basic tool of OR, applied to problem solving with the purpose of optimizing the system. Regardless of the type of model approached, LP has a versatility in formulating the constraints related to the management of forest operations (ÖHMAN; ERIKSSON, 2002).

The hypothesis of this study is that the management alternative with "q" $=1.5$, a residual basal area of 10 $\mathrm{m}^{2}$.ha-1 , for a 20 -year cutting cycle (CC) will be the alternative that maximizes the income in a native forest of $A$. Angustifolia. Thus, the objective of this study was to analyze two operational research problems, using integer linear programming, the former aiming to maximize the income for each scenario and the latter for the choice of the best management alternative for different De Liocourt quotients, residual basal area and cutting cycles.

\section{MATERIALS AND METHODS}

\section{Study Variables and Data Collection}

The study area located in the municipality of Lages is a residual of MOF, at an altitude of 1,200 m, and total area of 84 ha. The geographic coordinates of the site are $-27^{\circ} 49^{\prime}$ and $-50^{\circ} 06^{\prime}$. According to the Köppen classification, the site has a Cfb climate, hot temperate, with average temperature below $11.5^{\circ} \mathrm{C}$ in the coldest month below, and frost possibilities. The relative average humidity is $79 \%$. The average annual rainfall is 1,555.7 $\mathrm{mm}$ (ALVARES et al., 2014). Data for this study come from a systematic inventory, with sample sufficiency of 25 plots with an error limit of $15 \%$, thus 25 plots of $400 \mathrm{~m}^{2}(20 \mathrm{~m} \times 20 \mathrm{~m})$ were allocated, with spacing of $50 \mathrm{~m}$ between plots and $100 \mathrm{~m}$ between lines. In the survey, 332 trees were measured. From the diameter to the chest height of $10 \mathrm{~cm}$, dendrometric data were collected, with diameter at breast height (DBH), with the aid of a bevel gauge; total height (h) and height of insertion of the crown (Hic), measured with the Trupulse apparatus. To obtain the annual increment in diameter of trees of the diametric classes that compose the horizontal structure of the forest, the increment borer was used, removing two nondestructive perpendicular samples of increment rollers at the height of the DBH $(1.3 \mathrm{~m})$.

\section{Data processing}

Periodic Increment

The increase annual periodical percentage in volume (IPAv\%) For the area was calculated according to the equation adjusted by Costa et al. (2020) (equation 1). Considering the cutting cycles, the cutting intensity (equation 2) was determined by the Mexican thinning method and the cutoff rate (CR) using equation 3 .

$$
\begin{gathered}
\ln (I P A \%)=4.8269-1.1794 \ln (D B H) \\
C I=\left[1-\left(\frac{1}{(1+i)^{c c}}\right)\right] * 100 \\
C R=V r * \frac{I C}{100}
\end{gathered}
$$

where: IPA $\%=$ Increase annual periodical percentage in volume; $\mathrm{DBH}=$ diameter at breast height; $\mathrm{Nl}=\mathrm{Natural}$ logarithm; $\mathrm{CI}=$ cutting intensity, in percentage of volume; $\mathrm{i}=$ growth rate; $\mathrm{CC}=$ cutting cycle, in years; $\mathrm{CR}=\mathrm{Cutoff}$ rate in volume for CC; Av: Actual forest volume available, in cubic meters.

Tapering and Volume

To estimate the wood production in assortment classes, the thinning function proposed by Kozak (1988), adjusted by Costa et al., was used (2016) for the same area of study, with $\mathrm{R}^{2} \mathrm{aj}$. of $\approx 98.0 \%$ and Syx $\%$ of $17.4 \%$ (equation 4). The total bark volume of the tree $(\mathrm{m} 3 \mathrm{cc})$ up to the insertion point of the canopy was determined by

FLORESTA, Curitiba, PR, v. 50, n. 4, p. 1854 - 1863, out/dez 2020.

Souza, I. A et.al.

ISSN eletrônico 1982-4688

1855

DOI: $10.5380 /$ rf.v50 i4. 66459 
dividing the stem into sections of 5 and $5 \mathrm{~cm}$, adjusting the tapering and using the Smalian formula to calculate the volume of each section.

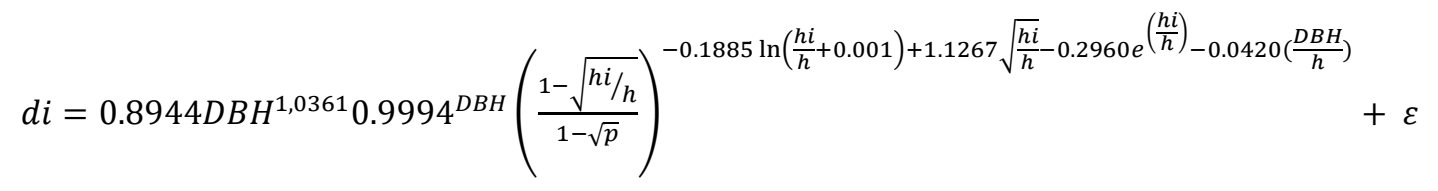

where: di $=$ relative diameter; $\mathrm{DBH}=$ diameter at breast height $(1.30 \mathrm{~m}) ; \mathrm{hi}=$ relative height; $\mathrm{h}=$ total height; $\mathrm{p}=$ inflection point considered at $1.3 / \mathrm{h} ; \mathrm{Ni}=$ natural logarithm; and $\varepsilon=$ error.

\section{Assortment}

The wood assortment (Figure 1) follows the methodology, also proposed by Costa et al. (2016). The following assortments with bark were considered: $\mathrm{A} 1=\mathrm{Log}$ for sawmill with diameter at the fine tip greater than and equal to $40 \mathrm{~cm}$ and length of 5.4 meters; A2 = Log for sawmill with diameter at the fine tip greater than or equal to $30 \mathrm{~cm}$ and less than $40 \mathrm{~cm}$ and length of 2.7 meters; $\mathrm{A} 3=\log$ with diameter at the fine tip greater than or equal to $20 \mathrm{~cm}$ and less than $30 \mathrm{~cm}$ and length of 2.2 meters; A4 = log for construction with diameter at the thin tip less than $20 \mathrm{~cm}$ and with the remainder of the available length of the stem.

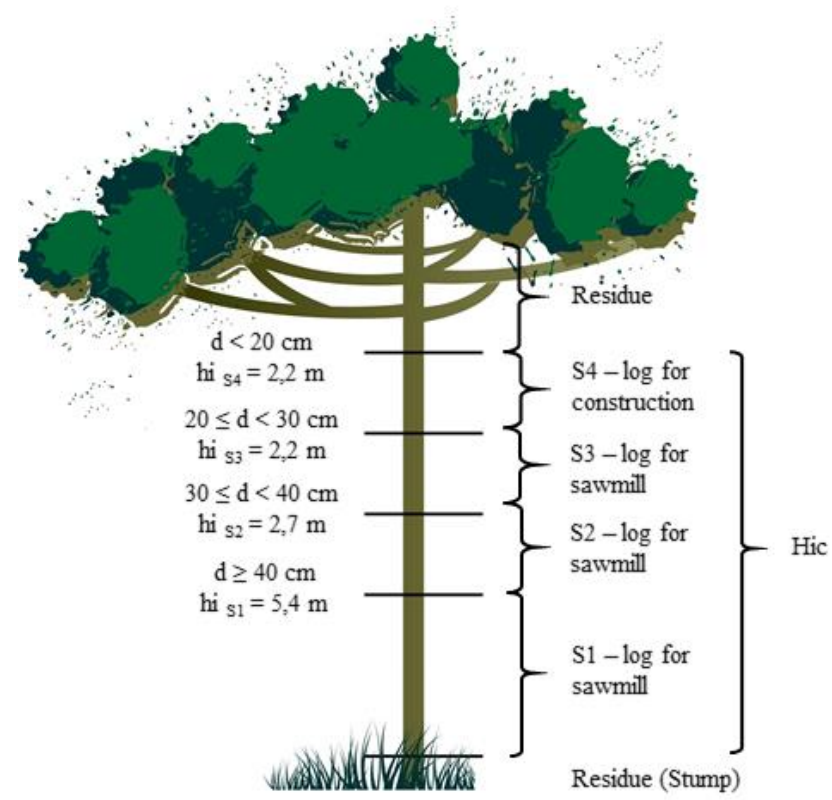

Figure 1. Classification of Assortments for A. Angustifolia.

Figura 1. Classificação de sortimento para A. Angustifolia.

Caption: d: diameter (cm), hi $\mathrm{S}_{\mathrm{S} 1}, \mathrm{hi}_{\mathrm{S} 2}, \mathrm{hi}_{\mathrm{S} 3}$ and hi $\mathrm{Si}_{\mathrm{S}}$ : height (m), A1: assortment 1, A2: assortment 2, A3: assortment 3, A4: assortment 4, hi: height of the log and Hic: height of insertion of the crown.

Income

The income value in $\mathrm{R} \$$ /tree was obtained by price research. Table 1 shows values considered for the classification of the tree. The price criterion for the individual tree considers the quality of the tree and the number of assortments generated.

Table 1. Income ( $\mathrm{R} \$$ tree) according to the quality classification and quantity of assortments generated.

Table 1. Receita (R $\$$ /árvore) conforme classificação de qualidade e quantidade de sortimento gerado.

FLORESTA, Curitiba, PR, v. 50, n. 4, p. 1854 - 1863, out/dez 2020.

Souza, I. A et.al.

ISSN eletrônico 1982-4688

DOI: $10.5380 /$ rf.v50 i4. 66459 


\begin{tabular}{ccccc}
\hline \multirow{2}{*}{ Number of logs } & \multicolumn{4}{c}{ Assortments } \\
\cline { 2 - 5 } & $\mathrm{A} 1$ & $\mathrm{~A} 2$ & $\mathrm{~A} 3$ & $\mathrm{~A} 4$ \\
\hline 1 & $\mathrm{R} \$ 300.00$ & $\mathrm{R} \$ 100.00$ & $\mathrm{R} \$ 30.00$ & $\mathrm{R} \$ 10.00$ \\
2 & $\mathrm{R} \$ 325.00$ & $\mathrm{R} \$ 150.00$ & $\mathrm{R} \$ 30.00$ & $\mathrm{R} \$ 15.00$ \\
3 & $\mathrm{R} \$ 350.00$ & $\mathrm{R} \$ 200.00$ & $\mathrm{R} \$ 50.00$ & $\mathrm{R} \$ 20.00$ \\
$4 / 5$ & - & $\mathrm{R} \$ 250.00$ & $\mathrm{R} \$ 75.00$ & $\mathrm{R} \$ 25.00$ \\
\hline
\end{tabular}

Caption: A1: assortment 1, A2: assortment 2, A3: assortment 3, A4: assortment 4.

Considering the temporal value of the financial resource, the net present value was calculated according to equation 5, assigning an interest rate (IR) of $6 \%$ to the period; the Brazilian forestry sector traditionally works with rates between 6 and 12\% (TSUKAMOTO, 2003). To calculate the cash flow, the costs were disregarded, since this is not practiced, we preferred to allocate the gross holding value.

$$
N P V=\sum_{t=1}^{n} \frac{C F_{t}}{(1+T x)^{t}}
$$

where: NPV: net present value; $\mathrm{CF}_{\mathrm{t}}$ : cash flow in the period of 20, 25 and 30 years; IR: Interest rate; t: period.

Scenarios for the Management of Araucaria

Three management regimens were suggested for three cutting cycles, based on studies conducted in the area by Silveira et al. (2017), in which the De Liocourt "q" quotient obtained was 1.32, for the desired maximum diameter of $42.5 \mathrm{~cm}$ and $4.69 \mathrm{~m}^{2} \cdot \mathrm{ha}^{-1}$ in the basal area explored. The scenarios analyzed were management regime with De Liocourt "q" quotient of 1.1; 1.3 and 1.5. All regimens will be evaluated for the residual basal area (Gr) of 10.0, 12.0 and $14.0 \mathrm{~m}^{2} \cdot \mathrm{ha}^{-1}$. The planning horizon was stipulated for three cutting cycles of 20,25 and 30 years for the three management regimes. With interventions every 5 years. The recipes obtained with each De Liocourt alternative and the assortments were considered the models for decision making. Thus, 27 scenarios were generated.

\section{Integer Linear Programming}

Selective cutting is a method that reconciles forest management and harvesting, aiming to identify and select individuals to be explored, considering ecological, economical and productive aspects in the wood supply of a forestry project. However, some problems arise, namely: how will these individuals be selected in the field? And, mainly, what trees $\mathrm{i}$ will be cut in the year $\mathrm{j}$ ? To solve this problem, the integer linear programming (ILP) was used in the forest management planning for the Araucaria species. The analysis of this research was conducted in 2 steps: 1 optimization of the management prescription and 2 - optimization of the forest planning problem.

The mathematical model I was structured with the objective of maximizing the income for each scenario. Restrictions have been incorporated to meet the options related to the selected management plan, such as restricting the number of trees/diameter class to be removed from the area. The equation (6) is the objective function of the model and seeks to maximize the sum of the income generated by the tree $i$ in the diametric class $j$. The restrictions relate to: (7) obey the concept of Balanced Forest and allow the tree i to be selected, which generates a volume v, throughout my diameter amplitude in the diametric class j, not greater than the $\mathrm{V}$ of the Management Plan; (8) respect the limit of trees $i$ to be withdrawn in the diameter class $j$ for each management plan; and (9) binary restriction $\{0.1\}$ for selection representing the activation or not of the cut of the tree $i$ in the diameter class $j$.

Objective Function

subject to

$$
\operatorname{Max} Z=\sum_{i=1}^{N} \sum_{j=1}^{P} r_{i j} x_{i j}
$$

$$
\begin{aligned}
& \sum_{i=1}^{N} v_{i j} x_{i j} \leq V_{j} \\
& \sum_{i=1}^{N} x_{i j}=N R_{i j} \\
& x_{i j}=\{1,0\}
\end{aligned}
$$

where: $\mathrm{Z}$ : vector resulting from the sum of the generated income of the trees $\mathrm{i}$ belonging to the diametric class $\mathrm{j}$; rij: income in reais of the tree $\mathrm{i}$ belonging to the diametric class $\mathrm{j}$; xij: binary decision variable $\{0.1\}$ employed to cut the

FLORESTA, Curitiba, PR, v. 50, n. 4, p. 1854 - 1863, out/dez 2020.

Souza, I. A et.al.

ISSN eletrônico 1982-4688 
tree $\mathrm{i}$ belonging to the diametric class $\mathrm{j}$; $\mathrm{N}$ : total number of inventoried trees in the study area; $\mathrm{P}$ : total number of diametric classes; vij: volume generated by the tree $\mathrm{i}$ belonging to the dimetric class $\mathrm{j}$; $\mathrm{Vj}$ : volume of the management plan allowed to be withdrawn from each dimetric class $\mathrm{j}$; NRij: number of trees $\mathrm{i}$ to be removed by diameter class $\mathrm{j}$ according to the management plan.

The proposed mathematical model II consists in defining the area to be managed in the proposed planning horizon that maximizes the income for all the scenarios studied, with cutting cycles of 20, 25 and 30 years. Volume and area restrictions were incorporated according to the prescriptions that each management plan allows it to be applied in the forest. The equation (10) is the objective function of the model and seeks to maximize the sum of the income generated by the area managed i in the year $\mathrm{j}$. The restrictions relate to: (11) volume allowed to be withdrawn from area $\mathrm{i}$ according to the management plan, in the year $\mathrm{j}$; and (12) the area to be managed $\mathrm{i}$ cannot exceed the total area of the forest fragments.

$$
\begin{aligned}
& \text { Objective Function } \\
& \qquad M a x Z=\sum_{i}^{N} \sum_{j=1}^{N} r_{i j} a_{i j} \\
& \text { subject to } \\
& \sum_{i}^{N} \sum_{j=1}^{N} a_{i j} y_{i j} \leq V \\
& \sum_{i}^{N} \sum_{i=1}^{P} a_{i j} \leq A
\end{aligned}
$$

Being: $\mathrm{Z}$ : vector resulting from the sum of the income generated by the area managed $i$ in the year $\mathrm{j}$; rij: income in reais generated by the area i managed in the year j, considering IR: $6 \%$ to the period; aij: area to be managed $\mathrm{i}$ in the year j; N: Number of cut-off periods $\mathrm{N}=5,10,15,20,25$ and 30 years; yij = volume harvested in area $\mathrm{i}$ in the year j; $\mathrm{V}=$ volume of the management plan allowed to be withdrawn in the forest; $\mathrm{A}=$ total area of the forest.

The models was processed in the Solver supplement from Microsoft Excel, version Office 365, and it is a tool that solves ILP problems. A computer with Intel® Core i5 $2.4 \mathrm{GHz}$ processor and $6 \mathrm{~Gb}$ of RAM was used.

\section{RESULTS}

\section{Model I: to maximize income}

The mathematical model proposed to select the trees to be managed, for each scenario proposed in MOF, generated a total volume with bark $\left(\mathrm{m}^{3} \mathrm{cc} \cdot \mathrm{ha}^{-1}\right)$ and income $\left(\mathrm{R} \$ \cdot \mathrm{ha}^{-1}\right)$. The valuation was based on the product of the number of logs per diametric class of each tree, with number of trees explored per hectare and respective prices. Considering the CC of 20, 25 and 30 years and based on the Periodic Annual Increment in Volume (\%) and with

\begin{tabular}{|c|c|c|c|c|c|}
\hline \multirow{2}{*}{$\begin{array}{l}\text { Cutoff } \\
\left(\mathrm{m}^{3} \mathrm{cc} \cdot \mathrm{ha}^{-1}\right.\end{array}$} & \multirow{2}{*}{$\begin{array}{l}\left.{ }^{-1}\right) \\
\text { Rate }\end{array}$} & \multirow{2}{*}{$\begin{array}{l}\mathrm{CC} \\
\text { (year) }\end{array}$} & \multicolumn{3}{|c|}{$\operatorname{Gr}\left(\mathrm{m}^{2} \cdot \mathrm{ha}^{-1}\right)$} \\
\hline & & & 10 & 12 & 14 \\
\hline \multirow{9}{*}{ Q } & \multirow{3}{*}{1.1} & 20 & 18.45 & 11.84 & 5.23 \\
\hline & & 25 & 21.90 & 14.06 & 6.20 \\
\hline & & 30 & 24.99 & 16.04 & 7.08 \\
\hline & \multirow{3}{*}{1.3} & 20 & 30.15 & 20.81 & 16.10 \\
\hline & & 25 & 35.80 & 24.71 & 19.12 \\
\hline & & 30 & 40.85 & 28.19 & 21.81 \\
\hline & \multirow{3}{*}{1.5} & 20 & 46.64 & 40.58 & 36.23 \\
\hline & & 25 & 55.38 & 48.18 & 43.01 \\
\hline & & 30 & 63.19 & 54.98 & 49.08 \\
\hline
\end{tabular}
cutting intensity for MOF, it was possible to determine the CR $\left(\mathrm{m}^{3} \mathrm{cc} \cdot \mathrm{ha}^{-1}\right)$ (Table 2) and income for each scenario ( $\mathrm{R} \$$ ha) (Table 3). The data will serve as input in model II to choose the best management plan.

Table 2. Determination of the sustained cutoff rate for the natural forest of A. angustifolia.

Tabela 2. Determinação da taxa de corte sustentada para a floresta natural de A. angustifolia.

Caption: CC: Cutting cycle, Gr: residual basal area and q: De Liocourt quotient.

FLORESTA, Curitiba, PR, v. 50, n. 4, p. 1854 - 1863, out/dez 2020.

Souza, I. A et.al.

ISSN eletrônico 1982-4688

DOI: $10.5380 /$ rf.v50 i4. 66459 
Table 3. Determination of gross income for the natural forest of A. angustifolia.

Tabela 3. Determinação da receita bruta da floresta natural de A. angustifolia.

\begin{tabular}{|c|c|c|c|c|c|}
\hline \multirow{2}{*}{\multicolumn{2}{|c|}{$\begin{array}{l}\text { Income } \\
\left(\mathrm{R} \$ \cdot \mathrm{ha}^{-1}\right)\end{array}$}} & \multirow{2}{*}{$\begin{array}{c}\mathrm{CC} \\
\text { (year) }\end{array}$} & \multicolumn{3}{|c|}{$\operatorname{Gr}\left(\mathrm{m}^{2} \cdot \mathrm{ha}^{-1}\right)$} \\
\hline & & & 10 & 12 & 14 \\
\hline \multirow{9}{*}{ Q } & \multirow{3}{*}{1.1} & 20 & $3.662,39$ & $2.412,65$ & $1.182,82$ \\
\hline & & 25 & $4.348,54$ & $2.864,67$ & $1.404,42$ \\
\hline & & 30 & $4.961,85$ & $3.268,69$ & $1.602,49$ \\
\hline & \multirow{3}{*}{1.3} & 20 & $5.762,15$ & 4., 217,62 & $3.300,67$ \\
\hline & & 25 & $6.841,71$ & $5.007,80$ & $3.919,06$ \\
\hline & & 30 & $7.806,64$ & $5.714,09$ & $4.471,79$ \\
\hline & \multirow{3}{*}{1.5} & 20 & $8.093,42$ & $7.143,91$ & $6.429,52$ \\
\hline & & 25 & $9.609,74$ & $8.482,34$ & $7.634,11$ \\
\hline & & 30 & $10.965,07$ & $9.678,67$ & $8.710,80$ \\
\hline
\end{tabular}

Caption: CC: Cutting cycle, Gr: residual basal area and q: De Liocourt quotient.

\section{Model II: definition of the area to be managed in the planning horizon}

The management alternative that maximized the income for the 20-year-old CC was the De Liocourt quotient of 1.3 , with a residual basal area of $12 \mathrm{~m}^{2}$.ha-1, the number of trees to be withdrawn for this management alternative is 45 trees.ha $^{-1}$, allowing interventions in the diametric class centers in the amplitude of 17.5 to $52.5 \mathrm{~cm}$ (Table 4), covering almost all the diametric classes of the Araucaria forest, enabling thus stability for this residual after management. The value that maximized the income for this management alternative was 200,512.85 reais for the total area of 84 ha to be explored.

For the 25 and 30-year-old CC, the management alternative that maximized the income was the De Liocourt quotient of 1.3, with a residual basal area of $12 \mathrm{~m}^{2} \cdot \mathrm{ha}^{-1}$ (Table 4). The value that maximized the income for the 25year-old CC was 203,079.15 and for the 30-year-old CC was 189,029.32 reais for the total area of 84 ha to be explored. Sensitivity analysis was calculated for the amplitude of 3 to $10 \%$ p.y. (Figure 2).

Table 4. Objective Function ( $\mathrm{R} \$$ ) for the A. angustifolia forest according to the management regimes stipulated for the $\mathrm{CC}$ of 20,25 and 30 years old.

Tabela 4. Função objetivo (R\$) para a floresta de A. angustifolia de acordo com os regimes de manejo estipulados para o CC de 20, 25 e 30 anos.

\begin{tabular}{|c|c|c|c|c|c|c|c|c|c|}
\hline \multirow[t]{2}{*}{$\mathrm{CC}$} & \multirow[t]{2}{*}{$q$} & \multirow[t]{2}{*}{$\mathrm{Gr}$} & \multicolumn{6}{|c|}{$\begin{array}{c}\text { Area to be managed by management } \\
\text { alternative and period }\end{array}$} & \multirow[t]{2}{*}{ OF } \\
\hline & & & 5 & 10 & 15 & 20 & 25 & 30 & \\
\hline \multirow{9}{*}{20} & 1.1 & 10 & 21.0 & 21.0 & 21.0 & 8.1 & & & $182,204.20$ \\
\hline & 1.1 & 12 & 21.0 & 21.0 & 7.2 & - & & & $137,094.78$ \\
\hline & 1.1 & 14 & 21.0 & 6.3 & - & - & & & $78,059.00$ \\
\hline & 1.3 & 10 & 21.0 & 21.0 & 21.0 & 21.0 & & & $195,916.03$ \\
\hline & 1.3 & 12 & 21.0 & 21.0 & 21.0 & 16.7 & & & $200,512.85$ \\
\hline & 1.3 & 14 & 21.0 & 21.0 & 20.7 & - & & & $173,349.49$ \\
\hline & 1.5 & 10 & 21.0 & 21.0 & 21.0 & 21.0 & & & $177,860.34$ \\
\hline & 1.5 & 12 & 21.0 & 21.0 & 21.0 & 21.0 & & & $180,460.16$ \\
\hline & 1.5 & 14 & 21.0 & 21.0 & 21.0 & 21.0 & & & $181,928.33$ \\
\hline
\end{tabular}

FLORESTA, Curitiba, PR, v. 50, n. 4, p. 1854 - 1863, out/dez 2020.

Souza, I. A et.al.

ISSN eletrônico 1982-4688 


\begin{tabular}{rrrrrrrrrr} 
& 1.1 & 10 & 16.80 & 16.80 & 16.80 & 16.80 & 9,72 & & $188,463.62$ \\
1.1 & 12 & 16.80 & 16.80 & 16.80 & 0.63 & - & & $149,963.41$ \\
& 1.1 & 14 & 16.80 & 10.44 & - & - & - & & $89,024.01$ \\
\hline \multirow{2}{*}{25} & 1.3 & 10 & 16.80 & 16.80 & 16.80 & 16.80 & 16.80 & & $191,487.97$ \\
& 1.3 & 12 & 16.80 & 16.80 & 16.80 & 16.80 & 16.80 & & $203,079.15$ \\
& 1.3 & 14 & 16.80 & 16.80 & 16.80 & 16.80 & 1.25 & & $181,665.60$ \\
\hline 1.5 & 10 & 16.80 & 16.80 & 16.80 & 16.80 & 16.80 & & $173,840.37$ \\
& 1.5 & 12 & 16.80 & 16.80 & 16.80 & 16.80 & 16.80 & & $176,381.43$ \\
& 1.5 & 14 & 16.80 & 16.80 & 16.80 & 16.80 & 16.80 & & $177,816.41$ \\
\hline \multirow{3}{*}{30} & 1.1 & 10 & 14.00 & 14.00 & 14.00 & 14.00 & 14.00 & 11,64 & $181,895.89$ \\
& 1.1 & 12 & 14.00 & 14.00 & 14.00 & 14.00 & 1.39 & - & $150,964.56$ \\
1.1 & 14 & 14.00 & 14.00 & 0.94 & 0.00 & - & - & $96,628.24$ \\
\hline 1.3 & 10 & 14.00 & 14.00 & 14.00 & 14.00 & 14.00 & 14.00 & $178,240.07$ \\
1.3 & 12 & 14.00 & 14.00 & 14.00 & 14.00 & 14.00 & 14.00 & $189,029.32$ \\
1.3 & 14 & 14.00 & 14.00 & 14.00 & 14.00 & 14.00 & 3.93 & $176,788.83$ \\
\hline 1.5 & 10 & 14.00 & 14.00 & 14.00 & 14.00 & 14.00 & 14.00 & $161,813.40$ \\
1.5 & 12 & 14.00 & 14.00 & 14.00 & 14.00 & 14.00 & 14.00 & $164,178.66$ \\
1.5 & 14 & 14.00 & 14.00 & 14.00 & 14.00 & 14.00 & 14.00 & $165,514.37$ \\
\hline
\end{tabular}

Caption: CC: Center class, q: De Liocourt quotient, Gr: residual basal area and OF: objective function.

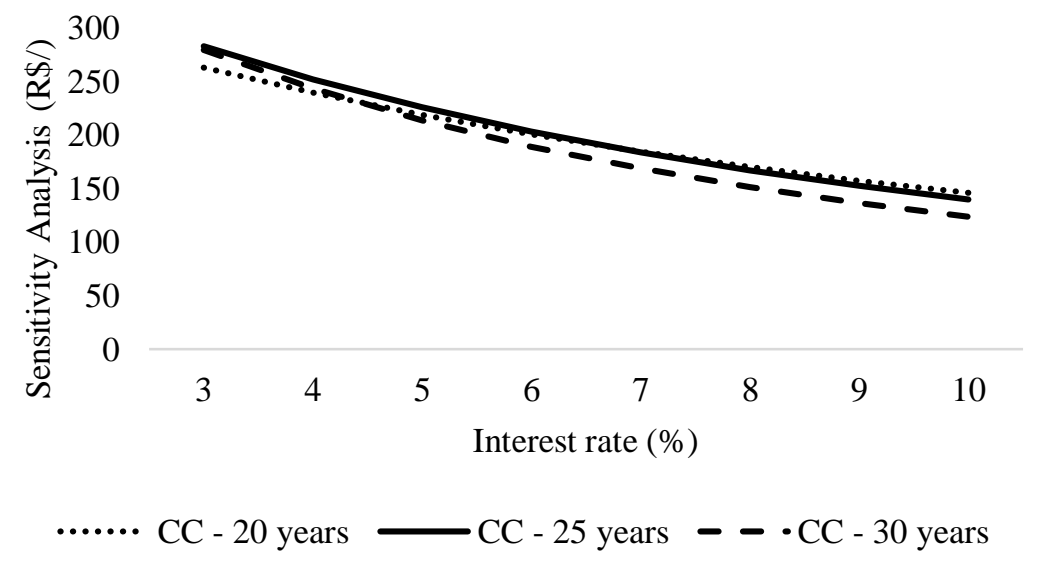

Figure 2. Sensitivity analysis for the best management alternative by CC.

Figura 2. Análise de sensibilidade para a melhor alternativa de manejo por CC.

\section{DISCUSSION}

Mixed forests become more prominent for forest management, due to the increasing evidence of their greater potential to provide ecological and socioeconomic goods and services, when compared with single-species forests (RIOFRÍO et al., 2017). The higher level and stability of productivity in mixed forests are of interest to many functions and services, besides being a precondition for the promotion of mixtures in forestry practice (DEL RIO et al., 2016). Although almost four decades without a management regime, the Araucaria forest presents growth and profitable production in the same pattern as the exotic forests of Pinus sp. However, this production due to the non-application of management regimes is compromised due to the stagnation increment, growth, diversity loss, impairment of

FLORESTA, Curitiba, PR, v. 50, n. 4, p. 1854 - 1863, out/dez 2020.

Souza, I. A et.al.

ISSN eletrônico 1982-4688

1860

DOI: $10.5380 /$ rf.v50 i4. 66459 
maintenance of the future diametric structure, low natural regeneration, low production of pine cones and competition, according to studies by Hess et al. (2018), Silveira et al. (2018) and Hess et al. (2019).

Forest management measures are a priority for the future conservation of the Araucaria forest. Studies on the diametric increment rate, prediction of production and forest management are consolidated, requiring the planning of alternative management for this forest typology, mainly as a safety measure at the time of the forestry intervention and the appropriate regime, differing from traditional practices that were applied in the forest.

In this context, decision-making in multiple management alternatives using operational research gains special attention as a tool in forest management, because it reduces risks and uncertainties as shown in our study. This is justified because the current structure of the Araucaria forest presents unbalanced diametric distribution, with different values of the De Liocourt quotient (' $q$ '), basal area and diameter increment rate. Thus, intervening in the structure of the forest based only on the 'q' value may not be the best choice in terms of ecosystem and socioeconomic functions.

The study showed that formulating problems by associating forest and economic technical information constraints indicate a viable solution for forest management. This indicates that the growth resumption, the conservation of the species and the economic viability for the $\mathrm{CC}$ are guaranteed. The study contributes to the knowledge necessary for the management of mixed forests, which according to Steckel (2019) can be more productive and are more resilient and resistant to abiotic disturbances.

The results showed that not all proposed management alternatives used the entire area of the forest available. This occurred because the problem is restrictive regarding the volumetric production and some of the management regimens tested have a smaller volume, not justifying their withdrawal and reducing the area to be managed (Table 2). Thus, the results show that lower De Liocourt quotients produce smaller volumes and assortments, as they remove more individuals from small diametric classes. Higher quotients and CC rates, on the other hand, increase the amount of wood removed.

The cutting intensity and the CR will increase the higher the CC because trees grow in size with age and increment rate. The compatibilization of $\mathrm{CC}$ with the pace of growth of the species to be managed is of paramount importance to the management success (PUTZ et al., 2000), because the period of time defined by the CC must ensure the sustainability of forest production, allowing the forest to restore the volume explored (SCHNEIDER; FINGER, 2000). Basal area variation is important because it provides different revenues, and it is also associated with the increment rate of each fragment, and the higher the rate, the faster the site returns to the production withdrawn. Thus, management alternatives should be evaluated by operational research, as it informs which will maximize the income and sustainable management.

With the price defined per individual tree standing, the ratio of the volume to be withdrawn to the quantity of trees in the management alternative ' $\mathrm{q}$ ' $=1.3$ with a residual basal area of $12 \mathrm{~m}^{2}$. ha $\mathrm{h}^{-1}$ is the one that best uses the forestry resource for the constraints established in the proposed conditions, so the problem tends to maximize income in this management alternative.

The De Liocourt ' $q$ ' quotient of 1.33 was considered the best alternative, where the classes of trees to be removed from 35 to $40 \mathrm{~cm}$ to a residual of MOF in the same region of this study, removing individuals in the intermediate and upper classes, proving forest resilience in recruiting individuals to these diameter classes (HESS et al., 2010). Still, in a natural residual Araucaria forest in the municipality of Painel, Santa Catarina, the De Liocourt ' $q$ ' quotient of 1.33 is elucidated as the best alternative; however, the trees of the diametric classes to be removed are 10, $15,40,45$ and $50 \mathrm{~cm}$ (HESS, 2012), thereby validating the data of this research.

The management alternative ' $\mathrm{q}$ ' of 1.5 and the residual basal area of 12 or $14 \mathrm{~m}^{2} \cdot \mathrm{ha}^{-1}$, for the same fragment of Araucaria, is considered the best management alternative as the trees to be removed would be in the classes of larger diameters and the classes with smaller diameters would have a higher number of trees, thus providing stability to the fragment (SILVEIRA et al., 2018)

The objective of defining the harvesting option on sustained bases for floodplain forests in the Amazonian estuary, maintaining the original structure of the diameter classes, with the original De Liocourt quotient is 1.74, but the results indicated that the forest can be managed by adopting the harvest plan using a De Liocourt quotient $50 \%$ higher than the original ('q' $=2.61$ ) and removal of $30 \%$ of the basal area, which corresponds to a potential profit of US\$ 3,945.40/ha (GAMA et al., 2005).

The forest management allied to assortment studies brings benefits beyond the financial and social to the local communities, adds environmental improvements such as the return in the increment rates (HESS et al., 2010; HESS et al., 2018b), increase in species diversity (HESS et al., 2010; HESS, 2012; HESS et al., 2018a), reduction of

FLORESTA, Curitiba, PR, v. 50, n. 4, p. 1854 - 1863, out/dez 2020.

Souza, I. A et.al.

ISSN eletrônico 1982-4688

1861

DOI: $10.5380 /$ rf.v50 i4. 66459 
competition (COSTA; FINGER, 2017), increase in the admission rate (HESS et al., 2014), in addition to reducing mortality and scarcity of resources of the forest ecosystem (ORELLANA; VANCLAY, 2018).

It also favors the natural regeneration, because the low regeneration in natural Araucaria forests is due to the thickening of the cups that do not allow the entry of light near the soil (SANT'ANNA et al., 2013; HESS et al., 2014). Thus, the forest management for the natural areas of Araucaria would bring social, environmental and financial benefits to the local populations.

\section{CONCLUSION}

- The mathematical models of the whole linear programming are essential in the operational planning of the forest harvesting, when the optimization of the process is objective, allowing the definition of which trees are taken from the forest among those susceptible to cut.

- CR will increase the higher the CC desired. The calculation of the income generated for the scenarios shows that the variation in basal area is important because it provides different revenues.

- Despite the application of different CC of 20,25 and 30 years, the management alternative that best used the resources and that maximize the income for the study area is " $\mathrm{q} "=1.3$ and residual basal area of $12 \mathrm{~m}^{2}$.ha ${ }^{-1}$

\section{REFERENCES}

ALVARES, C.A., STAPE, J.L., SENTELHAS, P.C., GONÇALVES, J.L. DE M., SPAROVEK, G. Meteorologische Zeitschrift. In: Koppen's climate classification map for Brazil. 2014, 711-728 p.

CAMPOS, B.P.F, BINOTI, D.H.B, SILVA, M.L., LEITE, H.G., BINOTI, M.L.M.S. Conversão de árvores em multiprodutos da madeira utilizando programação inteira. Revista Árvore, Viçosa-MG, v.37, n.5, p.881-887, 2013.

COSTA, E.A., FINGER, C.A.G. 2017. Efeito da Competição nas Relações Dimensionais de Araucária. Floresta Ambient, Rio de Janeiro, v. 24, 2017.

COSTA, E.A., FINGER, C.A.G., SCHNEIDER, P.R., HESS, A.F. Função de afilamento e sortimentos de madeira para Araucaria angustifolia. Ciência Florestal, Santa Maria, v. 26, n. 2, p. 523-533, 2016.

COSTA, E.A.; LIESENBERG, V.; HESS, A.F.; FINGER, C.A.G.; SCHNEIDER, P.R.; LONGHI, R.V.; SCHONS, C.T.; BORSOI, G.A. Simulating Araucaria angustifolia (Bertol.) Kuntze Timber Stocks With Liocourt's Law in a Natural Forest in Southern Brazil. Forests, Switzerland, v. 11, p. 339, 2020.

DEL RÍO, M., PRETZSCH, H., RUÍZ-PEINADO, R., AMPOORTER, E., ANNIGHÖFER, P., BARBEITO, I., BIELAK, K., BRAZAITIS, G., COLL, L. et al. Species interactions increase the temporal stability of community productivity in Pinus sylvestris-Fagus sylvatica mixtures across Europe. Journal of Ecology, London, v. 105, p. 10321043, 2016.

GAMA, J.R.V.; BENTES-GAMA, M. DE M.; SCOLFORO, J. R. Manejo sustentado para floresta de várzea na Amazônia Oriental. R. Árvore, Viçosa, v. 29, n. 5, p. 719-729, 2005.

GOMIDE, L.R., ARCE, J.E., SILVA, A.C.L. Uso do algoritmo genético no planejamento florestal considerando seus operadores de seleção. Cerne, Lavras, v. 15, n. 4, p. 460-467, 2009.

HESS, A, F., CAlGAROTTO, A.R., PINHEIRO, R., WANGINIAK, T. C. R. Proposta de manejo de Araucaria angustifolia (Bertol,) Kuntze utilizando o quociente De Liocourt e análise de incremento, em propriedade rural no município de Lages, SC. Pesquisa Florestal Brasileira, v. 30, p. 337 - 345. 2010.

HESS, A. F. Manejo de Araucaria angustifolia pelo quociente De Liocourt em propriedade rural no Município de Painel, SC. Pesquisa Florestal Brasileira, v. 32, p. 227 - 232, 2012.

HESS, A. F., MINATTI, M., FERRARI, L., PINTRO, B. A. Manejo de Floresta Ombrófila Mista pelo método De Liocourt, Município de Painel, SC. Cerne, Lavras, v. 20, p. 575 - 580. 2014.

HESS, A.F., LOIOLA, T., SOUZA, I.A., MINATTI, M., RICKEN, P., BORSOI, G. Forest management for the conservation of Araucaria angustifolia in southern Brazil. Floresta, Curitiba, v. 48, n. 3, p. 373-382, 2018(b).

FLORESTA, Curitiba, PR, v. 50, n. 4, p. 1854 - 1863, out/dez 2020.

Souza, I. A et.al.

ISSN eletrônico 1982-4688

DOI: $10.5380 /$ rf.v50 i4. 66459 
HESS, A.F., SIlVEIRA, A.C.DA., KREFTA, S.M., SANTOS, D.V.DOS., FILHO, M.D.H.V., ATANAZIO, K.A., SCHORR, L.P.B., SOUZA, I.A., BORSOI, G.B., STEPKA, T.F., COSTA, E.A., LIESENBERG, V. Crown dynamics of Brazilian pine (Araucaria angustifolia) in Santa Catarina region of Brazil. Aust. J. Crop Sci. Madison, v. 12, p. 449457, 2018(a).

JUSTEN, J.G.K, MULLER, J.J.V., TORESAN, L. Levantamento Socioambiental. In Inventário Florístico Florestal de Santa Catarina. Blumenau. Brasil. 2012, 242-259 p.

KOZAK, A. A variable-exponent taper equation. Canadian Journal of Forest Research, Ottawa, v. 18, p. 1363-1368, 1988.

ÖHMAN, K., ERIKSSON, L.O. Allowing for spatial consideration in long-term forest planning by linking linear programming with simulated annealing, Forest Ecology and Management, Netherlands. v. 161, n. 1, p. 221-230, 2002.

ORELlANA, E., FILHO, A.F., NETTO, S.P., DIAS, A.N. Modelagem da distribuição diamétrica de espécies florestais em um fragmento de floresta ombrófila mista. Revista Árvore, Viçosa-MG, v.38, n.2, p.297-308, 2014.

ORELlANA, E., VANCLAY, J.K. Competition and dominance between angiosperms and Araucaria angustifolia (Bert.) O. Kuntze in the Atlantic Forest in southern Brazil. Forest Ecology and Management. v. 425, p. 119-125, 2018.

PUTZ, F. E.; DYKSTRA, D. P.; HEINRICH, R. Why poor logging practices persist in the tropics. Conservation Biology, Malden, v. 14, n. 4, p. 951- 956, 2000.

RIOFRÍO, J., RÍO, M., BRAVO, H.P.F. Changes in structural heterogeneity and stand productivity by mixing Scots pine and Maritime pine. Forest Ecology and Management, Netherlands, v. 405, p. 219-228, 2017.

SANT'ANNA, C. S., SEBBENN, A. M., KLABUNDE, G. H. F., BITTENCOURT, R., NODARI, R. O., MANTOVANI, A., REIS, M. S. 2013. Realized pollen and seed dispersal within a continuous population of the dioecious coniferous Brazilian pine Araucaria angustifolia (Bertol.) Kuntze. Conservetion Genetic, Arlington, v. 14, n. 3, p. 601-613, 2013.

SCHNEIDER, P.R., FINGER, C.A.G. Manejo sustentado de florestas inequiâneas heterogêneas, Santa Maria: Imprensa Universitária/UFSM. Santa Maria, Brazil. 2000, 195p.

SILVEIRA, A.C., HESS, A.F, SCHORR, L.P.B., KREFTA, S.M., SANTOS, D.V., FILHO, M.D.H.V., ATANAZIO, K.M., COSTA, E.A., STEPKA, T.F., BORSOI, G.A. Management of Brazilian pine (Araucaria angustifolia (Bertol) Kuntze) based on the Liocourt model in a mixed ombrophilous forest in Southern Brazil. Autralian Journal of Crop Science, Austrália, v. 12, n. 02, p. 311-317, 2017.

STECKELA, M., HEYMA, M., WOLFF, B., REVENTLOWC, D.O.J., PRETZSCHA, H. Transgressive overyielding in mixed compared with monospecific Scots pine (Pinus sylvestris L.) and oak (Quercus robur L., Quercus petraea (Matt.) Liebl.) stands - Productivity gains increase with annual water supply. Forest Ecology and Management, Netherlands, v. 439, p. 81-96, 2019.

TSUKAMOTO, A.F.A., LOPES, M.S., COUTO, L., DIAS, M.M. Análise econômica de um plantio de teca submetido a desbastes, Revista Árvore, v. 27, n. 4, p. 487-494, 2003.

FLORESTA, Curitiba, PR, v. 50, n. 4, p. 1854 - 1863, out/dez 2020.

Souza, I. A et.al.

ISSN eletrônico 1982-4688 